\title{
Evaluation of a multimedia online tool for teaching bronchial hygiene to physical therapy students
}

\author{
Avaliação de um recurso multimídia para ensino de higiene brônquica para \\ estudantes de fisioterapia
}

Cibele C. B. Marques da Silva', Sonia L. P. Toledo², Paulo S. P. Silveira³, Celso R. F. Carvalho

\begin{abstract}
Background: Advances in information technology have been widely used in teaching health care professionals. The use of multimedia resources may be important for clinical learning and we are not aware of previous reports using such technology in respiratory physical therapy education. Objectives: Our approach was to evaluate a conventional bronchial hygiene techniques (BHTs) course with an interactive online environment, including multimedia resources. Methods: Previous developed audiovisual support material comprised: physiology, physiopathology and BHTs, accessible to students through the Internet in conjunction with BHTs classes. Two groups of students were compared and both attended regular classes: the on-line group $(n=8)$ received access to online resources, while the control group $(n=8)$ received conventional written material. Student's performance was evaluated before and after the course. Results: A preliminary test (score 0 to 10) was applied before the beginning of the course, showing that the initial knowledge of both groups was comparable [online, 6.75 (SD=0.88) vs. control, 6.125 ( $\mathrm{SD}=1.35) ; \mathrm{p}>0.05$ ]. Two weeks after the end of the course, a second test showed that the online group performed significantly better than the control group [respectively, 7.75 ( $S D=1.28)$ vs. 5.93 (SD=0.72); $p>0.05$ ]. Conclusions: The use of a multimedia online resource had a positive impact on student's learning in respiratory therapy field in which instrumental and manual resources are often used and can be explored using this technology.
\end{abstract}

Keywords: physical therapy modalities/education; internet/utilization; multimedia/utilization.

\section{Resumo}

Contextualização: As novas tecnologias da informação têm sido amplamente utilizadas no ensino em saúde. O uso de recursos multimídia pode ser importante para o aprendizado clínico, no entanto não há descrição na literatura da aplicação e relevância desses recursos para o ensino de fisioterapia respiratória. Objetivos: Avaliar o impacto de um recurso didático multimídia no ensino de manobras de higiene brônquica (MHB). Métodos: O material didático multimídia previamente elaborado foi dividido em três módulos: "princípios fisiológicos", "fisiopatologia" e "MHB", disponibilizado em diversos formatos (páginas on-line, apostila e recursos audiovisuais) e inserido em um ambiente colaborativo de aprendizagem na internet, compondo um curso sobre MHB. Foram comparados dois grupos de estudantes que tiveram aulas presenciais convencionais sobre MHB. Durante o curso, um grupo (on-line, $\mathrm{n}=8$ ) teve acesso ao recurso multimídia, enquanto o outro (controle, $n=8$ ) teve acesso ao material teórico convencional (textos e apostilas). O desempenho dos estudantes foi avaliado por dois testes (escore de 0 a 10) realizados antes e após o curso. Resultados: Nossos resultados mostram que o desempenho dos dois grupos foi similar no primeiro teste (on-line, $6,75( \pm 0,88)$ vs. controle, $6,125( \pm 1,35)$; $p>0,05)$. Duas semanas após o fim do curso, um segundo teste mostrou que o grupo on-line teve um desempenho melhor que o controle (respectivamente, $7,75( \pm 1,28)$ vs. $5,93( \pm 0,72) ; p<0,05)$. Conclusões: $O$ uso de um recurso multimídia on-line teve um impacto positivo no aprendizado de estudantes de fisioterapia respiratória, área na qual os recursos instrumentais e manuais são frequentemente utilizados e podem ser explorados no contexto deste tipo de tecnologia.

Palavras-chave: modalidades de fisioterapia/educação; internet/utilização; multimídia/utilização.

Received: 07/27/2011 - Revised: 10/21/2011 - Accepted: 10/25/2011

${ }^{1}$ Physical Therapy Departament, School of Medicine, Universidade de São Paulo (USP), São Paulo, SP, Brazil

${ }^{2}$ School of Medicine, USP, São Paulo, SP, Brazil

${ }^{3}$ Medical Informatics, Department of Pathology, School of Medicine, USP, São Paulo, SP, Brazil

Correspondence to: Celso Ricardo Fernandes Carvalho, Faculdade de Medicina, Universidade de São Paulo, Departamento de Fisioterapia, Rua Cipotânea, 51, CEP 05360-160, São Paulo,

SP, Brazil, e-mail: cscarval@usp.br 


\section{Introduction $: \because \therefore$}

Traditionally, the teaching of health professionals is performed through theoretical and practical classes, and the consultation material consists of books and scientific journals. Now with the availability of new technologies and opportunities to teachers and students are opened. The use of these new technologies, however, have been a target of ongoing debate ${ }^{1-3}$, as well as the need for the development of new strategies that favor the improvement of teaching standards ${ }^{4}$.

A variety of studies have acknowledged the benefits of using information technology as a teaching tool in various healthrelated fields, such as osteopathy $y^{5,6}$, dentistry ${ }^{7-9}$, and nursing ${ }^{10,11}$. In Physical Therapy (PT), studies involving the application of information technology have evaluated the impact of the use of computers $^{12-14}$ and compared its use with traditional learning ${ }^{15}$. These studies suggest that computer may be used to improve PT students' learning. To the best of our knowledge, although these new technologies seem to provide a variety of teaching opportunities $^{16}$, there are no reports of applications designed to teach bronchial hygiene techniques (BHT) to PT students.

Here, we compared the performance of two groups of PT students before and after a BHT's course. Our interest was to evaluate potential learning benefit when the students had online or conventional consultation materials.

\section{Methods $: \because$.}

\section{Online resources available}

The online course was developed and organized in modules as previous decribed for Marques da Silva, Carvalho and Carvalho $^{17}$. The modules are available in a system named COL - "Cursos On-Line - Online courses" (www.col.usp.br), and its exclusive access to online users via login and password. Each module consisted of a theoretical component (booklet), multimedia resources (figures, videos, and graphic animations), and interactive components (discussion list among instructors and students, a system with online tests, and links to selected information of other websites). The booklets containing evidence-based information was based on Medline and EMBASE databases ${ }^{18-21}$. Videos were, on average, three minutes in length and $3 \mathrm{MB}$ in size. Some videos were accompanied by animation sequences illustrating physiopathological conditions. External links were used to guide the students to further references. All resources were developed taking into account uniformity of approach, clarity for the student, easiness of use, and were integrated through a collaborative learning environment, where students could exchange information and discuss with the teachers. The booklets were available in PDF version created in Adobe Acrobat Writer 6.0 software; the hypertext interface was written using XML Notepad 2007; online pages were developed in HTML, JavaScript and CSS; figures and pictures were produced in Adobe Photoshop CS 8.0; and videos were edited in Sony Vega 7.0 software. Access to the online interface was accomplished using Microsoft Internet Explorer 7.0.

The BHT module comprised three topics: physiology of the mucociliary system, physiopathology of diseases that lead to hypersecretion, and BHTs (Figure 1). The physiology of the mucociliary system included mucociliary function, mucous functions, mucous formation and structure, and factors that affect the defense mechanisms. The physiopathology of diseases that lead to hypersecretion approached bronchitis, bronchiectasis, cystic fibrosis, asthma, immotile cilia syndrome, and postoperative profile; clinical profile of each disease was discussed. Finally, the BHTs module comprised vibration/compression, high-frequency oscillation, use of a vibrating vest, percussion, total slow expiration with open glottis, active cycle of breathing, autogenic drainage, cough, postural drainage and aerosol therapy. The definition, application, positioning, materials needed and contraindications for each technique were presented. The most relevant information was highlighted, as suggested by Palloff, Pratt and Rapp ${ }^{22}$.

\section{Evaluation of the teaching resources}

Sixteen students (12 females; $25.43 \mathrm{SD}=5.42$ years) from the $4^{\text {th }}$ year of an undergraduate degree in Physical Therapy at a public university agreed to participate in the study. They signed written informed consent according to the Ethics Committee of the Clinics Hospital (Comissão de Ética para Análise de Projetos de Pesquisa do Hospital das Clínicas da Faculdade de Medicina da Universidade de São Paulo (USP), São Paulo, SP, Brazil - CAPPesq - Process 1043/03). The participants were randomly assigned (by coin toss) into two groups. The online group $(n=8)$ was allowed online access to the system described above, while the control group $(n=8)$ was provided with conventional written material (Figure 2). An initial, supervised multiple-choice test in a computer room at the University was performed to ensure that the control and the online groups had no initial knowledge differences.

Both groups attended the conventional course classes. After the end of the course both groups had access to the teachers to ask questions and to study, respectively, their online or conventional material along two weeks. The access to the online material was then discontinued, and, after two additional weeks, all students were submitted to a final test, which was similar to the first test. Both tests scored from 0 to 10 points. 


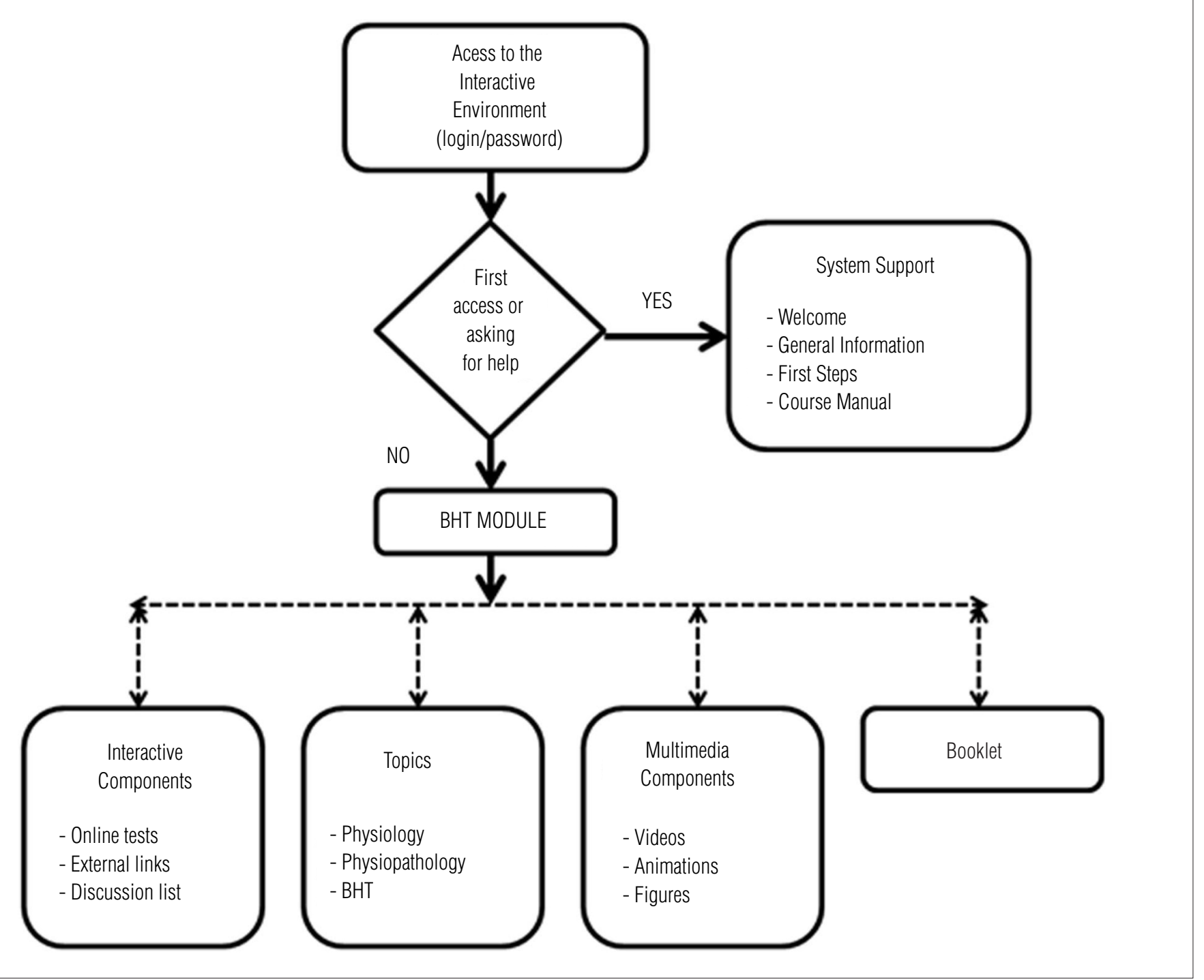

Figure 1. Overview of student's access to the module BHT (Bronchial Hygiene Techniques) in the interactive learning environment. Solid arrows indicate the mandatory direction to be followed by the students during the online access. Dashed arrows indicate student's free choice access according to their better interest.

A two-weeks interval between the end of the online access and the final test was intended to avoid short-term memory influences. The questions for the initial and final tests were independently developed by five physical therapists, who did not attend the course. The 20 questions assessing the knowledge of the students addressed the three divisions of the module, as it follows: therapeutic indications (eight questions); contraindications for the use of BHTs (six questions); and concepts (six questions). Each correct question scored 0.5 .

\section{Statistical analysis}

The scores of each group were submitted to the KolmogorovSmirnov and Levene tests to evaluate the normality and homogeneity of the data, respectively. The initial and final performances of each participant were evaluated using a one-way analysis of variance (ANOVA) and submitted to the Holm-Sidak post hoc test. The level of significance was set at $5 \%$.

\section{Results $: \because$}

There was no between-group differences in performing the tests at baseline (initial test), [Online group 6.75 ( $\mathrm{SD}=0.88$ ) and $6.13(\mathrm{SD}=1.35), \mathrm{p}>0.05]$. On the final test, the students in the online group performed significantly better than the control group [7.75 $( \pm 1.28)$ and $5.93( \pm 0.72)$, respectively; $\mathrm{p}<0.05]$ (Figure 3). 


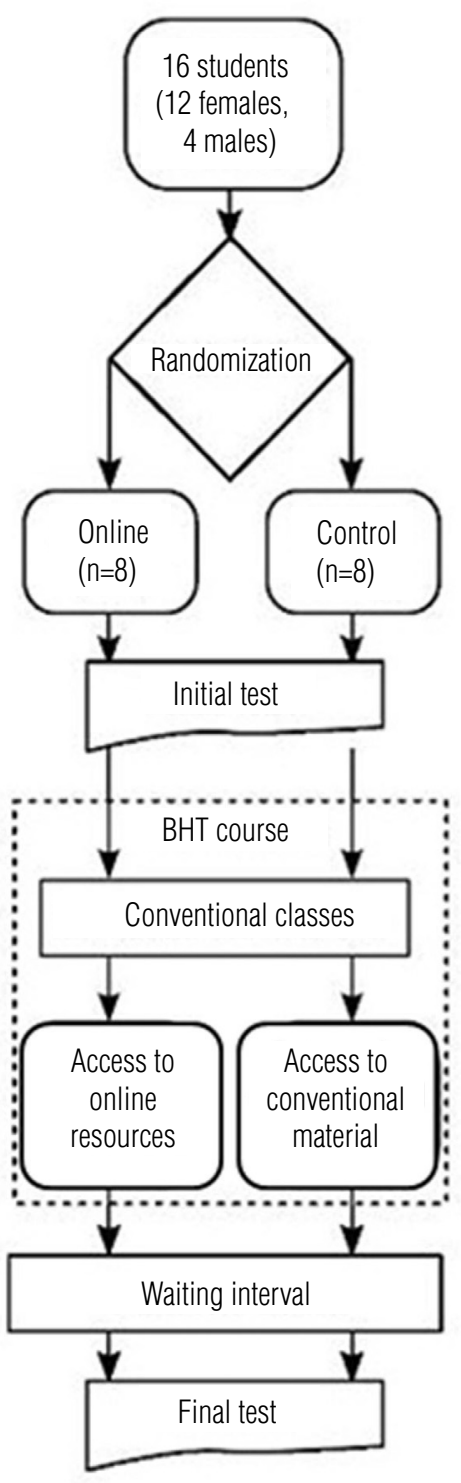

BHT=Bronchial Hygiene Techniques.

Figure 2. Flowchart of student's participation.

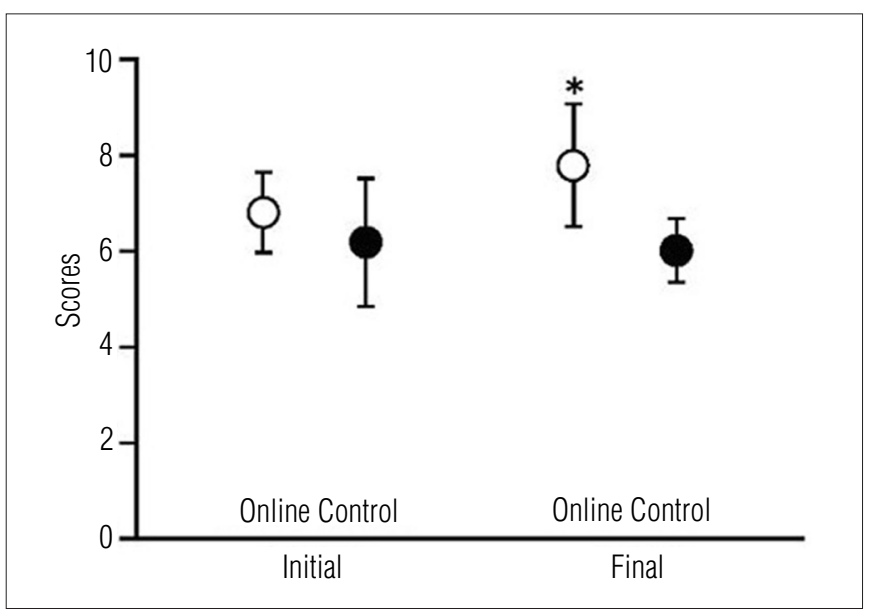

Figure 3. Performance of the Online and Control groups on the initial and final tests.

\section{Discussion $: \because$.}

Our results showed that the use of a multimedia online resource had a positive impact on student's learning in respiratory therapy, field in which instrumental and manual resources are often used and can be explored using this technology. To our knowledge, this is the first study evaluating the use of online support through the Internet for teaching BHTs to PT students. In a previous study ${ }^{17}$, our group described, step by step, the development of a multimedia tool for teaching bronchial hygiene available on the internet, however, this was only a descriptive study and this tool's effectiveness in the student's learning was unknown. Our approach was not to compare conventional versus distance courses ${ }^{23-26}$, but to offer a hybrid course where a conventional course was combined with online support and multimedia resources.

Increased motivation of the students ${ }^{27}$, cost-effectiveness and user preferences ${ }^{15}$ may be partial explanations for such better performance. Even when no difference is found, students may still rather prefer to use the system ${ }^{15}$ and augmented motivation may favour improved student scores or make students to finish the tests faster than the control group ${ }^{14}$. Specially, when questions of the test show figures, students that had access to computer aided instructions tend to have higher scores, suggesting that the computers can reinforce visual comprehen$\operatorname{sion}^{13}$. In addition, tools that allow tutor-student interaction also seem to be important in improving learning ${ }^{28}$.

The use of these technologies has been frequently mentioned in other health-related fields. For instance, Chamberlain and Yates ${ }^{5}$ developed teaching materials and found increased recognition of ostheopaty principles in daily practice. Lowe, Wright and Bearn ${ }^{7}$ compared the benefits of classroom instruction with those of a program of computerised learning for orthodontics and found that students using the computerised program acquired knowledge in a similar or even more efficient manner. Most studies evaluating effectiveness of the use of new technologies have compared distance learning with regular classroom learning ${ }^{23-26}$. Instead, the present study evaluated improvements in student learning using online tools as adjuvants to regular learning, because we understand that distance learning cannot replace the clinical qualification of a good teacher. In order to get the best of two worlds, the knowledge acquired by the students must be complemented by the advantages of online learning, which includes the facility of formatting and easiness of access, material tailored to individual needs, access from multiple sources, capacity to access links and other websites, incorporation of multimedia materials, relatively low cost, non-linear mode of learning and promotion of high inter- 
activity between students and tutors as well as among the students themselves ${ }^{8}$.

The educational process has been a target of ongoing debate, as has the need to develop new strategies that favour the improvement of teaching standards ${ }^{4}$. A major concern regarding the use of new technologies is the development of critical thinking, defined as the capacity to analyse, evaluate, question, investigate and experiment ${ }^{29,30}$. A number of studies have demonstrated that applying new technological tools to teaching promotes critical thinking ${ }^{6,31,32}$. In the teaching-learning process, information technology and communication have a diversity of uses that go beyond the transfer of information through classes and from textbooks to students through distance learning ${ }^{33}$. In the resource developed, a written material providing scientific evidence of the effectiveness of the BHTs was also made available to students. Although the effectiveness of some BHTs is still in question $^{18-21}$; we understand that it is essential for students to have access to this evidence-based knowledge and use it to reflect on their practice. Some studies evaluating the impact of online multimedia resources used to improve the qualification of health care professionals have shown promising results ${ }^{12,34}$. In addition, access to written material also seems to be important for stimulating review and reinforcing the knowledge imparted in the classroom, when necessary ${ }^{1,34}$. In the present study, this educational aspect was taken into consideration, which is why we made it possible to access and print the booklet.

Studies carried out in the fields of health care have demonstrated improved learning among students taught using technological resources ${ }^{5-11}$. However, although technology can facilitate and enrich learning, it can create problems as well. One of the biggest problems faced was the access to the BHTs videos, which were, on average, $3 \mathrm{MB}$ in size. Some participants of the online group, who did not have access to broadband internet reported difficulties in viewing these videos. These technological issues must be solved with online support, supplied, in our course, through a collaborative learning environment, where students could exchange information and discuss with the teachers and the technical assistance team. Various studies have suggested that similar technical problems, as well as social factors and poor skills in using technological resources are the major barriers encountered by students in using these technologies ${ }^{12,35,36}$. Allen et al. ${ }^{1}$ identified possible reasons why students resist using this technology: they might consider it susceptible to failure; they might be incapable of working with computers; and they might believe the computer experience incapable of replacing traditional classes. This last argument does not apply to our material, since it was developed as adjuvant to the traditional learning. One of the advantages of our approach is that teachers continue to be essential to the success of the teaching-learning process, where the technology does not have the role of teaching but facilitating it. Students do not learn from technology, but from instructors who must be trained to communicate through technology ${ }^{37}$. Despite the benefits obtained by the students in our study, we consider the sample size is a limitation and the use of this technology in a larger number of students should be further tested.

\section{Acknowledgments $\because:$.}

The computer team, Cintia Medeiros Ferreira, Ethel Shuna Queiroz and Rogerio Alexandre Scripnic Xavier Santos, for their support along the course development. The development of the system was provided by the Discipline of Telemedicine and by the Executive Director of the School of Medicine, José Agenor Mei Silveira, who made the necessary human resources available.

The Fundação de Amparo à Pesquisa do Estado de São Paulo (FAPESP), São Paulo, SP, Brazil and Conselho Nacional de Desenvolvimento Científico e Tecnológico (CNPQ), Brasília, DF, Brazil.

\section{References $: \because$.}

1. Allen M, Bourhis J, Burrell N, Mabry E. Comparing student satisfaction with distance education to traditional classrooms in higher education: a meta-analysis. Am J Distance Educ. 2002;16(2):83-97.

2. Williams $P$, Nicholas D, Gunter B. E-learning: what the literature tell us about distance education: An overview. Aslib Proc. 2005;57(2):109-22.

3. Premkumar K, Ross AG, Lowe J, Troy C, Bolster C, Reeder B. Technology-enhanced learning of community health in undergraduate medical education. Can J Public Health. 2010;101(2):165-70.

4. Jones LE. Introducing the ICF: the development of an online resource to support learning, teaching and curriculum design. Physiotherapy. 2011;97(1):55-8

5. Chamberlain NR, Yates HA. Use of computer-assisted clinical case (CACC) SOAP note exercise to assess students' application of osteopathic principles and practice. J Am Osteopath Assoc. 2000;100(7):437-40
6. Brahler CJ, Quitadamo IJ, Johnson EC. Student critical thinking is enhanced by developing exercise prescriptions using online learning modules. Adv Physiol Educ. 2002;26(1-4): 210-21.

7. Lowe $\mathrm{Cl}$, Wright JL, Bearn DR. Computer-aided learning (CAL): an effective way to teach the Index of Orthodontic Treatment Need (IONT)? J Orthod. 2001;28(4):307-11.

8. Grimes EB. Student perceptions of an online dental terminology course. J Dent Educ. 2002;66(1):100-7.

9. Browne L, Mehra S, Rattan R, Thomas G. Comparing lecture and e-learning as pedagogies for new and experienced professionals in dentistry. Br Dent J. 2004;197(2):95-7.

10. Cooper $C$, Taft $L B$, Thelen M. Examining the role of technology in learning: an evaluation of online clinical conferencing. J Prof Nurs. 2004;20(3):160-6. 
11. Harrington SS, Walker BL. The effects of computer-based training on immediate and residual learning of nursing facility staff. J Contin Educ Nurs. 2004;35(4):154-63.

12. Williams $P$. The learning web: the development, implementation and evaluation of internet-based undergraduate materials for the teaching of key skills. Active Learning in Higher Education. 2002;3(1):40-53.

13. Sanford MK, Hazelwood SE, Bridges AJ, Cutts JH 3rd, Mitchell JA, Reid JC, et al. Effectiveness of computer-assisted interactive videodisc instruction in teaching rheumatology to physical and occupational therapy students. J Allied Health. 1996;25(2):141-8.

14. Kinney P, Keskula DR, Perry JF. The effect of a computer assisted instructional program on physical therapy students. J Allied Health. 1997;26(2):57-61.

15. Veneri $D$. The role and effectiveness of computer-assisted learning in physical therapy education: a systematic review. Physiother Theory Pract. 2011;27(4):287-98.

16. Goldschalk DR, Lacey L. Learning at distance. Technology impacts on planning education. Journal of Planning Education and Research. 2001;20(4):476-89.

17. Marques Da Silva CCB, Carvalho SLPT, Carvalho CRF. Desenvolvimento de um recurso didático multimídia para 0 ensino de higiene brônquica. Fisioter Pesqui. 2009;16(1):76-81.

18. American Association for Respiratory Care. AARC Clinical Practice Guideline. Postural Drainage Therapy. Respir Care. 1991;36(12):1418-26.

19. Fink JB, Mahlmeister MJ. High frequency oscillation of the airway and chest wall. Respir Care. 2002;47(7):797-807.

20. Goodfellow LT, Jones M. Bronchial hygiene therapy. From traditional hands-on techniques to modern technological approaches. American Journal of Nursing. 2002;102(1):37-43.

21. Lapin CD. Airway physiology, autogenic drainage, and active cycle of breathing. Respir Care. 2002;47(7):778-85.

22. Palloff $R$, Pratt $K$, Rapp C. Building learning communities in cyberspace: effective strategies for the online classroom. San Francisco: Jossey-Bass Inc.; 1999.

23. Ritchie H, Newby T. Classroom lecture/discussion vs. live televised instruction: A comparison of effects on student performance, attitude, and interaction. Am J Distance Educ. 1989;3(3): $36-45$.
24. Cheng HC, Lehman J, Armstrong P. Comparison of performance and attitude in traditional and computer conferencing classes. Am J Distance Educ. 1991;5(3):51-64.

25. Köymen U. Comparison of learning and study strategies of traditional and open-learning-system students in Turkey. Distance Education. 1992;13(1):108-17.

26. Souder WE. The effectiveness of traditional vs. satellite delivery in three management of technology master's degree programs. Am J Distance Educ. 1993;7(1):37-53.

27. Thomas KJ, Denham BE, Dinolfo JD. Perceptions among occupational and physical therapy students of a nontraditional methodology for teaching laboratory gross anatomy. Anatomical Sciences Education. 2011;4(2):71-7.

28. Wen CL, Silveira PSP, Azevedo RS, Böhm GM. Internet discussion lists as an educational tool. J Telemed Telecare. 2000;6(5):302-4.

29. Facione NC, Facione PA. Externalizing the critical thinking in knowledge development and clinical judgment. Nurs Outlook. 1996;44(3):129-36

30. Jacobs PM, Ott B, Sullivan B, Ulrich Y, Short L. An approach to defining and operationalizing critical thinking. J Nurs Educ. 1997;36(1):19-22.

31. Loos G, Diether JW. Occupational safety and health training on the Internet. Developing quality instruction. AAOHN J. 2001;49(5):231-4.

32. Peters MW, Smith MF, Smith GW. Use of critical interactive thinking exercises in teaching reproductive physiology to undergraduate students. J Anim Sci. 2002;80(3):862-5.

33. Guri-Rosenblit S. Distance education' and 'e-learning': not the same thing. Higher Education. 2005;49(4):467-93.

34. Donnelly AB, Agius RM. The distance learning courses in occupational medicine -20 years and onwards. Occup Med (Lond). 2005;55(4):319-23.

35. Comeaux P. The impact of an interactive distance learning network on classroom communication Communication Education.1995;44(4):353-61.

36. Howard D. Enhanced by technology, not diminished: a practical guide for effective, distance communication. New York, NY: McGraw-Hill; 2002.

37. Cyrs TE. New directions for teaching and learning. San Francisco: Jossey-Bass; 1997 